\title{
Probability of pregnancy before ninety days postpartum in water buffal oes
}

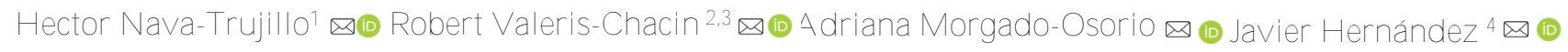

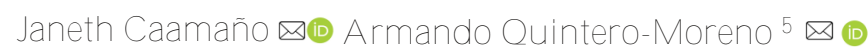

Producción A nimal, Instituto de Investigaciones A gropecuarias, Facultad de Ciencias Forestales y Ambientales, Universidad de los Andes, Mérida, Mérida, Venezuela.

\begin{abstract}
A bstract. This study aimed to assess the effect of parity and season of calving on the probability of water buffalo cows becoming pregnant in the first 90 days ( $\leq 90$ days) postpartum. A retrospective analysis of 3.181 pregnancies from 1.465 water buffal oes was carried out. Buffaloes were grouped according to parity in one, two, or three and more calvings. Season of calving was established as follows: long photoperiod (March-August) and short photoperiod (September-February). Predicted probabilities from the mixed-effects logistic regression model were calculated, and a generalized linear mixed model was fitted with random intercepts to calculate the log odds of becoming pregnant $\leq 90$ days postpartum. The probability of pregnancy $\leq 90$ days postpartum was 0.3645 , and it was lower in primiparous (0.2717) than in two-calved (0.3863) and three or more calving (0.5166). Probability of pregnancy $\leq 90$ days postpartum increased 1.77 odds by each increase in parity. The probability of becoming pregnant $\leq 90$ days postpartum was greater in water buffaloes calving during the short photoperiod season than those calving in the long photoperiod season ( 0.4239 vs. $0.2474, P>0.000)$. The latter only had 0.2645 odds to become pregnant than those calving during the short photoperiod season. The negative effect of long photoperiod was observed indifferently of parity. In conclusion, primiparity and the long photoperiod affected water buffalo cow's reproductive performance, decreasing pregnancy probability during the first 90 days postpartum.
\end{abstract}

Keywords: Water buffalo cows, anestrus, parity, photoperiod, season, probability of pregnancy.

\section{Probabilidad de preñez antes de los noventa días postparto en búfalas de agua}

Resumen. Este estudio tuvo como objetivo determinar el efecto del número de partos y de la época de partos sobre la probabilidad de preñez en los primeros 90 días $(\leq 90)$ postparto en búfalas de agua. Se realizó un análisis retrospectivo de los registros reproductivos de 1465 búfalas de agua (3 181 preñeces). Las búfalas se agruparon según el número de partos en uno, dos o tres y más partos; mientras que la época de partos se creó con los siguientes valores: fotoperiodo largo (marzo-agosto) y fotoperiodo corto (septiembrefebrero). Se calcularon las probabilidades de preñez mediante el modelo de regresión logística de efectos mixtos, y se ajustó un modelo lineal mixto generalizado con intersecciones aleatorias para determinar los odds logarítmicos para la preñez $\leq 90$ días postparto. La probabilidad de preñez $\leq 90$ días postparto fue de 0.3645 , y fue menor en primíparas (0.2717) en comparación con las búfalas de dos (0.3863) y tres o más partos (0.5166). La probabilidad de preñez $\leq 90$ días postparto aumentó 1.77 odds por cada aumento en el número de partos. La probabilidad de preñez $\leq 90$ días postparto fue mayor en las búfalas de agua que parieron durante la época de fotoperiodo corto ( 0.4239 vs 0.2474 , P> 0.000), que las que parieron en la época de fotoperiodo largo. Además, las últimas tuvieron solo 0.2645 odds de preñez que aquellas que parieron durante la época de fotoperiodo corto. El efecto negativo del fotoperiodo largo se observó indistintamente del número de partos. En conclusión, la primiparidad y el fotoperíodo prolongado afectaron el desempeño reproductivo de las búfalas de agua, disminuyendo la probabilidad de preñez durante los primeros 90 días postparto.

Pal abras clave: Búfalas de agua, anestro, número de partos, fotoperiodo, época, probabilidad de preñez

Recibido: 2021-01-04. Aceptado: 2021-04-01

${ }^{1}$ Corresponding author. Email: hectornava00@gmail.com

2Department of Veterinary and Biomedical Sciences, College of Veterinary Medicine, University of Minnesota, Saint Paul, MN, USA.

${ }^{3}$ Departamento de Sanidad A nimal y Salud Pública, Facultad de Ciencias Veterinarias, Universidad del Zulia, Maracaibo, Zulia, Venezuela.

4Produccion Vegetal, Instituto de Investigaciones Agropecuarias, Facultad de Ciencias Forestales y Ambientales, Universidad de los Andes, Mérida, Mérida, Venezuela.

5Laboratorio de Andrología, Facultad de Ciencias Veterinarias, Universidad del Zulia, Maracaibo, Zulia, Venezuela. 


\section{Introduction}

The profitability of buffalo production systems largely depends on an excellent reproductive efficiency (Shah et al., 1991; Sweers et al., 2014), and to achieve this goal, a calving to conception interval $\leq 90$ days is necessary. Buffaloes with low reproductive efficiency generate economic losses. Water buffaloes with delayed conception are 24 to $27 \%$ less profitable than those becoming pregnant earlier (Khan et al., 2008), and each extra day of calving interval, above the herd average, generate a decrease in earnings of $\$ 1.87$ (Safari et al., 2019).

A low reproductive performance implies greater costs by feeding and medicines, more non-productive days, decreased milk yield, less economic return for commercializing non-pregnant buffaloes, decreased number of replacements, males to sale, and sale of potentially productive animals (Shah et al., 1991; Cicek et al., 2017; Khan et al., 2008; Ribeiro et al., 2012; Safari et al., 2019). In this scenario, achieve the goal of getting the buffaloes pregnant $\leq 90$ days postpartum is a priority, although it can be challenging because several factors affect the reproductive performance of buffaloes (N ava-Trujillo et al., 2020b).
Parity and season of calving affect reproductive performance. Primiparous buffaloes have longer calving to first mount/ service, more prolonged calving to conception interval, lower pregnancy rate, and longer calving interval (Hassan et al., 2017; ElTarabany 2018; Nava-Trujillo et al., 2018; Nava-Trujillo et al., 2019; Nava-Trujillo et al., 2020a). Similarly, long photoperiod season promotes similar effects, and water buffaloes calving during spring and summer have lower reproductive performance than those calving in autumn and winter (Hassan et al., 2017; Ramadan 2018; Nava-Trujillo et al., 2019; Nava-Trujillo et al., 2020a). Realize the postpartum moment when buffal oes become pregnant, and identifying the nonpregnant buffaloes during the early postpartum, is of great interest. It will allow establishing a plan to control the postpartum anestrous period and to shorten the calving to conception interval in high-risk groups to ensure that most buffaloes get pregnant at the correct time. Therefore, this research aimed to determine the probability of water buffaloes became pregnant in the first 90 days postpartum and to establish whether parity and season of calving affected the achievement of this reproductive target.

\section{M aterials and $M$ ethods}

This is a retrospective study analyzing reproductive records of 1465 crossbred (Murrah/Mediterranean) water buffalo cows from three herds, including a total of 3181 pregnancies for eight years (2010 - 2018). The farms were located in Jesus María Semprún county, Zulia State, Venezuela, a tropical moist forest, with a mean daily temperature of $28.3^{\circ} \mathrm{C}$, a mean relative humidity of $80 \%$, and rainfall of $1800-3800 \mathrm{~mm} /$ year (Ewel et al., 1976). In the farms, animals grazed in pastures of Brachiaria humidicola and Brachiaria arrecta in one to two-day paddock rotations, with access to fresh water and a commercial mineral mix ad libitum. Mechanical milking was performed twice a day after a short time of suckling (1-3 min) by the water buffalo's own calf to stimulate milk letdown. During the milking, the calf remained bound to the water buffalo forelimb, and after milking, the calves suckled their dams to remove residual milk from the udder. Buffalo cows were served by natural mount, and an entry water buffal o bull for every 30-40 cows was present 24 hours during the year-round. The farmers kept paper records of each water buffalo cow. Additionally, in each farm, a preventive medicine standard program that included procedures to diagnose, prevent, and treat prevalent diseases and the application of mandatory vaccines against brucellosis, bovine rabies, clostridial diseases, leptospirosis, and foot and mouth disease was carried out.

\section{Statistical analysis}

Information about parity, the month of calving, and pregnancy status at day 90 postpartum were obtained from the records. Variable calving season was created as follows: March-August (long photoperiod) and September-February (short photoperiod). The main predictors were parity (categorized as one, two, or three and more calvings) and calving season. The outcome of interest was a binary variable about the pregnancy status at 90 days postpartum (pregnant or non-pregnant).

A generalized linear mixed model was fitted with random intercepts to the log odds of becoming pregnant $\leq 90$ days postpartum, which were regressed on parity and season of calving. All analyses were performed in Stata 15.1, and comparisons were adjusted by Sidak's method, in which the significance level to reject the null hypothesis was $1-(1-\alpha) 1 / k(\alpha$ : familywise error rate, 0.05 ; $k$ : number of pre-planned 
probabilities from the mixed-effects logistic regression model were calculated through the command margins
(Stata 15.1). Differences were considered statistically significant when $P$ values were $\leq 0.05$.

\section{Results}

The general probability of pregnancy $\leq 90$ days postpartum was 0.3645 (95\% Cl: $0.3465-0.3825)$, and this probability increased as parity increases: 0.2717 (95\% Cl: $0.2500-0.2935$ ) for primiparous buffaloes, 0.3863 (95\% Cl: $0.3665-0.4062)$ for two-calved buffaloes and 0.5166 (95\% Cl: $0.4811-0.5521)$ for buffaloes with $\geq 3$ calving $(P<0.000)$. As the number of calving increases, the odds of becoming pregnant in the first 90 days postpartum increased 1.7738 times (95 $\% \mathrm{Cl}$ : 1.5654 times - 2.01 times, $\mathrm{P}<0.000$ ).

In water buffaloes calving during short photoperiod season probability of pregnancy during the first 90 days postpartum was 0.4239 (95\% Cl: $0.4014-0.4465)$, and it was greater than in buffaloes calving in the long photoperiod season $(0.2474 ; 95 \% \mathrm{Cl}$ : $0.2197-0.2750$; $\mathrm{P}$ $<0.000$ ). The odds of becoming pregnant $\leq 90$ days postpartum in water buffaloes calving during the long photoperiod season were 0.2645 times $(95 \% \mathrm{Cl}$ : 0.1627 times - 0.4298 times, $\mathrm{P}<0.000$ ) than in those calving during the short photoperiod season.

The positive effect of increasing parity on the probability of pregnancy $\leqslant 90$ days postpartum was observed regardless of calving season. Likewise, the negative effect of calving during the long photoperiod season was observed in all parity categories (Table 1).

Table 1. Effect of parity and calving season on the predicted probability of pregnancy $\leq 90$ days postpartum in water buffaloes.

\begin{tabular}{ccccc}
\hline Parity & \multicolumn{3}{c}{ Season } \\
\cline { 2 - 5 } & \multicolumn{2}{c}{ Short photoperiod } & \multicolumn{2}{c}{ Long photoperiod } \\
\cline { 2 - 5 } & Adjusted probability & $95 \% \mathrm{Cl}$ & Adjusted probability & $95 \% \mathrm{Cl}$ \\
\hline 1 & $0.3315^{\mathrm{aA}}$ & 0.3020 & $0.1530^{\mathrm{aB}}$ & 0.1259 \\
& & 0.3610 & & 0.1802 \\
2 & $0.4483^{\mathrm{bA}}$ & 0.4242 & $0.2636^{\mathrm{bB}}$ & 0.2326 \\
& & 0.4725 & & 0.2938 \\
& & 0.5305 & $0.4094 \mathrm{CB}$ & 0.3446 \\
& $0.5706^{\mathrm{CA}}$ & 0.6106 & & 0.4742 \\
\hline
\end{tabular}

Values from the same column with different lowercase letters are significantly different $(P<0.05)$. Values from the same row with different uppercase letters are significantly different $(P<0.05)$.

\section{Discussion}

In this study, parity and calving season affected the probability of buffalo cows became pregnant in the first 90 days postpartum. The probability of pregnancy increased as parity increased, and therefore, primiparous buffaloes had the lowest probability of pregnancy. This likely occurs due to the greater incidence of anestrus observed in this group of buffaloes (Sosa et al., 2016). Jamuna et al. (2015) observed that primiparous buffaloes had a longer interval to first service and conception than multiparous; and it was recently observed that primiparous buffaloes had a more extended anestrus period (30 extra days) and a lower probability of having the first mount before 60 and 100 days postpartum compared with multiparous buffaloes (Nava-Trujillo et al., 2019). Also, the reproductive performance of primiparous buffaloes was related to milk yield, and those with greater milk yield had a lower pregnancy rate, longer calving interval, and lower probability to a calving interval $\leq 400$ days (Jamuna and Chakravarty, 2016; Nava-Trujillo et al., 2020a). Milk yield determines the energy balance, and as primiparous buffaloes are still growing, they develop a more profound negative energy balance, affecting their reproductive performance (Vecchio et al., 2007). A longer calving interval was observed in primiparous buffaloes having their first calving older (Zicarelli 2007), while younger buffaloes to the first cal ving had a service period 31.85 days shorter (Verma et al., 2018). Additionally, as herds used in this study practice suckling to induce milk letdown before milking, ovarian activity resumption may be delayed (Qureshi and Ahmad, 2008; Rijasnaz et al., 2014; Kantharaja et al., 2018). It seems that primiparous buffaloes are more sensitives to the negative effect of suckling than multiparous buffaloes (El-Fouly et al., 1976).

The reproductive activity of water buffaloes increases during the short photoperiod season (Zicarelli 2009; Gasparrini 2019; Nava-Trujillo et al., 2019), and the long photoperiod negatively affects 
reproductive performance, as observed in the present study. The probability of pregnancy $\leq 90$ days postpartum was lower in buffaloes calving during the long photoperiod season, regardless of parity. This was probably due to the delay in the resumption of ovarian activity and the lower fertility observed during this season, which generated a lengthening of the interval to the first service and conception, respectively. Estrus activity is lower during the long photoperiod season, and only $29.4 \%$ of mounts occurred this season (Nava-Trujillo et al., 2019). Moreover, water buffaloes calving during this season has a lower probability of being mounted during the first 60 and 100 days postpartum than calving during the short photoperiod season (Nava-Trujillo et al., 2019); even hypothalamus, hypophysis, and follicles are less responsive to exogenous hormones during the long photoperiod season (Barile et al., 2015). Lower pregnancy rates were observed during the long photoperiod season (El-Tarabany 2018; Dharap 2016; Qayyum et al., 2018), and a high incidence of embryo mortality has also been reported. Di Francesco et al. (2012) observed $7.3 \%$ of late embryo mortality in autumn and $23 \%$ during the transition to long photoperiod $(P<0.05)$. In Pakistan, a $60 \%$ pregnancy loss was reported between May-July in contrast with the $33 \%$ observed between September and December (Qayyum et al., 2017). All these findings occur because, in the season of long photoperiod, the corpus luteum receive lower blood flow and produce lower progesterone, affecting embryo development and survival; and smaller embryos have a greater probability of mortality (Campanile et al., 2005; Russo et al., 2010; Di Francesco et al., 2012; N eglia et al., 2012; Balestrieri et al., 2013).

Nevertheless, the effect of the season could be modulated by other factors. It was observed that parity affects calving concentration, and heifers are less seasonal than multiparous (Zicarelli 1994; Borghese et al., 1995; Ceron-Muñoz et al., 2017). The increase in the intake of metabolizable energy, zinc, and calcium and a decrease in crude protein consumption, magnesium, phosphorus, and copper were associated with the onset of the breeding season.(Qureshi et al., 1999a). In addition, in Colombia, Sánchez et al. (2017) observed a higher frequency of calving and conceptions in months with a decrease of daily temperature and relative humidity and increased rainfall. In contrast, Sertu et al. (2012) suggested that the supply of forage is a factor involved in the reproductive seasonality of the species.

\section{Conclusions}

The present study results showed that primiparous buffaloes and those calving during the season of long photoperiod have a high risk of reproductive failure, it is a lower probability of becoming pregnant $\leq 90$ days postpartum. Therefore, based on these results, it is recommended to establish a plan including nutritional, management, genetic, and hormonal strategies to cope with the harmful effects of the first calving and the long photoperiod to improve the reproductive performance of water buffalo cows.

Animal use and care: In this study, data collection did no required interactions with animals.

Conflict of interests: The authors disclose no conflict of interest.

\section{Literature Cited}

Balestrieri, M.L., Gasparrini, B., Neglia, G., Vecchio, D., Strazzullo, M., Giovane, A., Servillo, L., Zicarelli, L., D'Occhio, M.J., Campanile, G. 2013. Proteomic profiles of the embryonic chorioamnion and uterine caruncles in buffal oes (Bubalus bubalis) with normal and retarded embryonic development. Biol. Reprod., 88(5), 119. https:/ / doi.org/ 10.1095/ biolreprod.113.108696

Barile, V.L., Terzano, G.M., Pacelli, C., Todini, L., Malfatti, A., Barbato, O. 2015. LH peak and ovulation after two different estrus synchronization treatments in buffalo cows in the daylightlengthening period. Theriogenology, 82(2), 286-293. https:/ / doi.org/ 10.1016/ j.theriogenology.2015.03.0 19
Borghese, A., Barile, V.L., Terzano, G.M., Pilla, A.M., Parmeggiani, A. 1995. Melatonin trend during season in heifers and buffalo cows. Bubalus Bubalis., 1, 61-65.

Campanile, G., Neglia, G., Gasparrini, B., Galiero, G., Prandi, A., Di Palo, R., Michael, J.D., Zicarelli, L. 2005. Embryonic mortality in buffaloes synchronized and mated by AI during the seasonal decline in reproductive function. Theriogenology, 63(8), 2334-2340. https:/ / doi.org/ 10.1016/ j.theriogenology.2004.10.0 12

Cerón-Muñoz, M.F., Agudelo-Gómez, D.A., Ramírez-A rias, J.P. 2017. Estacional idad de partos de búfalas en Colombia. Livest Res Rural Dev., 29, Article 38. . 
Cicek, H., Tandoga, M., Uyarlar, C. 2017. Financial Iosses due to fertility problems in Anatolian dairy buffalo. Indian J. Anim. Res., 51(6), 1144-1148. https:/ / doi.org/ 10.18805/ ijar.10981

Dharap, A. Effect of season on pregnancy rates, milk progesterone, and milk melatonin profiles in water buffalo reared in Canada. Master Thesis. The University of Guelph. Guelph, Ontario, Canada. 2016; 94 pp. https:/ / cutt.ly/ IQj7hBI

El-Fouly, M.A., Kotby, E.A., El-Sobhy, A.E. 1976. Postpartum ovarian activity in suckled and milked buffal oes. Theriogenology, 5, 69-79. https:/ / doi.org/ 10.1016/ 0093-691X(76)90170-9

El-Tarabany, M.S. 2018. Survival analysis and seasonal patterns of pregnancy outcomes in Egyptian buffaloes. Livest Sci., 213, 61-66 https:/ / doi.org/ 10.1016/ j.livsci.2018.05.008

Ewel, J., Madriz, A., Tosi, A. Bosque húmedo tropical. En: Zonas de vida de Venezuela. Ministerio de Agricultura y Cría/ Dirección de Investigación. 2da Ed. Editorial Sucre Caracas Venezuela. 264 pp. 1976.

Gasparrini B. 2019. Effect of reproductive season on embryo development in the buffalo. Reprod. Fert. Dev., 31, 68-81. https:/ / doi.org/ 10.1071/ RD18315

Jamuna, V., Patil, C,S., Chakeavarty, A.K. 2015. Influence of non-genetic factors on performance traits in Murrah buffaloes. Indian J. Anim. Res., 49(3), 279-283. https:/ / doi.org/ 10.5958/ 09760555.2015.00089.8

Jamuna, V., Chakravarty, A.K. 2016. Evaluation of fertility in relation to milk production and productivity of Murrah buffaloes. Anim. Reprod. Sci., 171, 72-80. https:/ / doi.org/ 10.1016/ j.anireprosci.2016.06.001

Kantharaja, K.J., Tomar, A.K.S., N ataraju, O.R., Naveen Kumar, B.T. 2018. Effects of weaning and sex of calf on postpartum resumption of reproduction in mother buffaloes. Int. J. Curr. Microbiol. App. Sci., 7(5),

734-737.

https:/ / doi.org/ 10.20546/ ijcmas.2018.705.088

Khan, S., Qureshi, M.S., Ahmad, N., Amjed, M., Durrani, F.R., Younas, M. 2008. Effect of pregnancy on lactation milk value in dairy buffaloes. AsianAustralas. J. Anim. Sci., 21, 523-531. https:/ / doi.org/ 10.5713/ ajas.2008.70349

Kumar, P.R., Shukla, S.N., Shrivastava, O.P., Purkayastha, R.D. 2013. Incidence of postpartum anestrus among buffaloes in and around Jabalpur. Vet. World, 6(9), 716-719. https:/ / doi.org/ 10.14202/ vetworld.2013.716-719

Nava-Trujillo, H., Escalona-Muñoz, J., CarrilloFernandez, F., Parra-Olivero A. 2018. Effect of parity on productive performance and calving interval in water buffaloes. J. Buffalo Sci., 7, 13-16. https:/ / doi.org/ 10.6000/ 1927-520X.2018.07.01.3
Nava-Trujillo, H., Valeris-Chacin, R., Morgado-Osorio, A., Valero-Guerra, J. 2019. Effect of parity and season of calving on the postpartum reproductive activity of water buffalo cows. Bulgarian J. Anim. Husbandry (Zhivotnovadni Nauki), 56(4), 3-12. https:/ / cutt.ly/ WQj74CB

Nava-Trujillo, H., Valeris-Chacin, R., QuinteroMoreno, A., Escalona-Muñoz, J. 2020a. Milk yield at first lactation, parity, and season of calving affect the reproductive performance of water buffalo cows. Anim. Prod. Sci., 60(8), 1073-1080 https:/ / doi.org/ 10.1071/ AN 18420

Nava-Trujillo, H., Valeris-Chacin, R., Morgado-Osorio, A., Zambano-Salas, S., Tovar-Breto, L., QuinteroMoreno, A. 2020b. Reproductive performance of water buffalo cows: a review of affecting factors. J. Buffalo Sci., $133-151$. https:/ / doi.org/ 10.6000/ 1927-520X.2020.09.15

Neglia, G., Vecchio, D., Di Palo, R., Pacelli, C., Comin, C., Gasparrini, B., Campanile, G. 2012. Efficacy of PGF2 $\alpha$ on pre-ovulatory follicle and corpus luteum blood Flow. Reprod Dom. Anim., 47, 26-31. https:/ / doi.org/ 10.1111/ j.1439-0531.2011.01794.x

Qayyum, A., Arshad, U., Yousuf, M.R., Ahmad, N. 2018. Effect of breeding method and season on pregnancy rate and embryonic and fetal losses in lactating Nili-Ravi buffaloes. Trop. Anim. Health Prod., 50, 555-560 https:/ / doi.org/ 10.1007/ s11250 017-1468-4

Qureshi, M.S., Ahmad, N. 2008. Interaction of calf suckling, use of oxytocin and milk yield with reproductive performance of dairy buffaloes. A nim. Reprod. Sci., 106(3-4), 380-392. https:/ / doi.org/ 10.1016/ j.anireprosci.2007.05.019

Ramadan, S.I. 2018. Effect of some genetic and nongenetic factors on productive and reproductive traits of Egyptian buffaloes. J. Adv. Vet. Anim. Res., 5(4),

374-380. https:/ / doi.org/ 10.5455/ javar.2018.e287

Ribeiro, E.S., Galvão, K.N., Thatcher, W.W., Santos, J.E.P. 2012. Economics aspects of applying reproductive technologies to dairy herds. Anim. Reprod., 9(3), 370-387. https:/ / cutt.ly/ OQj5iPZ

Rijasnaz, V.V., Mondal, S.K., Fahim, A. 2014. Effect of weaning on the postpartum reproductive performance of Murrah buffaloes. Indian J. Anim. Res., 48(5), 501-503 https:/ / doi.org/ 10.5958/ 09760555.2014.00019.3

Russo, M., Vecchio, D., Neglia, G., Pacelli, C., Prandi, A., Gasparrini, B., Zicarelli, L., D’Occhio, M.J., Campanile, G. 2010. Corpus luteum function and pregnancy outcome in buffaloes during the transition period from breeding to non-breeding 
Safari, A., Shadparvar, A.A., Hossein-Zadeh, N.G., A bdollahi-Arpanahi, R. 2019. Economic values and selection indices for production and reproduction traits of Iranian buffaloes (Bubalus bubalis). Trop. Anim. Health Prod., 51(5), 1209-1214 https:/ / doi.org/ 10.1007/ s11250-019-01811-7

Shah, S.N.H., Dijkhuizen, A.A., Willemse, A.H., Van der Wiel, D.F.M. 1991. Economic aspects of reproductive failure in dairy buffaloes of Pakistan. Prev. Vet. Med., 11, 147-155. https:/ / doi.org/ 10.1016/ s0167-5877(05)80036-4

Sosa, A.S.A., Mahmoud, K.Gh.M., Kanddiel, M.M.M.,, Eldebaky, H.A.A., Nawito, M.F., Abou El-Roos, M.E.A. 2016. Genetic polymorphism of luteinizing hormone receptor gene in relation to fertility of Egyptian buffalo. BioTechnology, 12(5), 1-11. https:/ / cutt.ly/ XQj5jNK

Sweers, W., Mohring, T., Muller, J. 2014. The economics of water buffalo Bubalus bubal is breeding, rearing and direct marketing. Archiv. fur Tierzucht., 57, 111. http:/ / dx.doi.org/ 10.7482/ 0003-9438-57-022

Vecchio, D., Neglia, G., Rendina, M., Marchiello, M., Balestrieri, A., Di Palo, R. 2007. Dietary influence on primiparous and pluriparous buffalo fertility. Ital. J. Anim. Sci., 6(Supp 1), 512-514, https:/ / doi.org/ 10.4081/ ijas.2007.1s.512
Verma, R., Singh, I., Balhara, A.K., Nayan, V., Kumar Sharma, R., Chaudhiry, V. 2018. Correlation between extremes age at first calving with their productive and reproductive performances in Indian Murrah buffaloes (Bubalus bubalis). Indian J. Anim. Res., 52(10), 1506-1512. https:/ / doi.org/ 10.18805/ ijar.B-3371

Vittinghoff, E., Glidden, D.V., Shiboski, S.C., McCulloch, C.E. 2012. Regression methods in biostatistics: linear, logistic, survival, and repeated measures models. 2nd edn. (Springer: N ew York)

Zicarelli L. 1994. Management in different environmental conditions. Buf. J., Suppl. 2, 17-38.

Zicarelli, L. 2007. Can we consider buffalo a non precocious and hypofertile species?. Ital. J. Anim. Sci., 6(Supl 2), 143-154, https:/ / doi.org/ 10.4081/ ijas.2007.s2.143

Zicarelli, L. 2009. Enhancing reproductive performance Zicarelli, L. 2009. Enhancing reproductive performance in domestic dairy water buffalo (Bubalus bubalis). Soc. Reprod. Fertil. Suppl., 67:443455.

https:/ / doi.org/ 10.7313/ upo9781907284991.034 